\title{
Climate change and cattle farming
}

Statham, J.M.E., Green, M.J., Husband, J.A., Huxley, J.N.

\section{Figure 1 Intergovernmental climate change policy summary}

\section{Introduction}

'Global warming' and 'climate change' have become familiar household terms. However much confusion prevails over these issues that suffer with an incomplete scientific foundation and are often influenced by politics as much as by science. Climate change has entered the public debate globally. It is widely expected to have severe social, economic and environmental effects by many climate scientists through rising sea levels, changing weather patterns and temperature rises that will challenge society through compromised food production \& water availability. International policy aims to lower the greenhouse gas (GHG) emissions that are thought to be responsible for climate change (see figure 1; IPCC, 2014).

However, challenges exist in achieving binding transnational agreements. The Kyoto Protocol of 1992 committed industrialised countries to reduce their GHG emissions by at least 5\% below 1990 levels by 2012. The USA refused to sign this commitment amidst concerns of compromised competitiveness. Following the Copenhagen Summit in 2009, a last minute 'Copenhagen Accord' was agreed by USA, China, Brazil \& S. Africa, backed by the EU and the other 193 nations present. This accord "recognised" the goal of restricting global warming to $20 \mathrm{C}$ to prevent "dangerous climate change" but did not actually endorse the 2oC. Further progress was made at the Climate Conference in Cancun, Mexico, in 2010 but it was not until April 2016 that the 196 parties to the United Nations Framework Convention of the Climate Change (UNFCCC) signed the Paris Agreement on Climate Change (2015). With this, all countries pledged to work to limit the temperature rise overall below 2 degrees Celsius, but are aiming to achieve a temperature rise below 1.5 degrees.

The UK Climate Change Act (2008) outlines one of the most ambitious national climate change programmes, targeting reduced GHG emissions by $34 \%$ by 2020 and $80 \%$ by 2050 compared to 1990 levels (Statham and others, 2012). The EU has committed to the "20-20-20 goals"; a reduction in EU GHG emissions of at least $20 \%$ below 1990 levels; that $20 \%$ of EU energy consumption is to come from renewable resources; and a $20 \%$ reduction in primary energy use by 2020 (Kyoto Protocol Convention 1998).

Green House Gas (GHG) emissions

Five major sectors make up total anthropogenic GHG emissions:

- Energy

- Industry

- Waste

- Land use, land use change \& forestry (LULUCF)

- Agriculture

Overall, livestock activities were postulated to contribute an estimated $18 \%$ to these total GHG emissions (United Nations Food \& Agriculture Organisation, FAO 2006); although this figure has been extensively challenged and subsequently revised downwards. Livestock was 
attributed a $50 \%$ share of the last two categories (LULUCF \& agriculture) and nearly $80 \%$ of all agricultural emissions. In 2010 the FAO produced a 'lifecycle assessment' (LCA) of the dairy sector which was proposed to contribute $4 \%$ to the total global man made GHG emissions.

Livestock contribution to the four principal GHG:

1. Carbon dioxide

Livestock were attributed 9\% of global anthropogenic carbon dioxide emissions (FAO 2006). There are considerable uncertainties in these estimates, which include deforestation for feedcrop land and pasture as well as land degradation. Although less significant than LULUCF, intensification of livestock production is tending to increase fossil fuel use and hence carbon dioxide emissions.

In 2007, the dairy sector emitted 1,969 million tonnes of $\mathrm{CO}_{2}$ equivalent emissions [ $\pm 26 \%$ ] of which 1,328 million tonnes were attributed to milk, 151 million tonnes to meat from culled animals, and 490 million tonnes to meat from fattened calves (FAO 2010).

\section{Methane}

Livestock were attributed $35-40 \%$ of global anthropogenic methane emissions (FAO 2006). $80 \%$ of agricultural methane emissions were due to enteric fermentation \& manure.

Methane contributes most to the global warming impact of milk: $52 \%$ of GHG emissions from both developing and developed countries (FAO 2010).

\section{Nitrous oxide}

Livestock were attributed $65 \%$ of global anthropogenic nitrous oxide emissions (FAO 2006); the most potent of the three major GHG. This represents $75-80 \%$ of all agricultural emissions (FAO 2010).

\section{Ammonia}

Livestock were attributed $64 \%$ of global anthropogenic ammonia emissions (FAO 2006); even though the resulting air and water pollution have generally been regarded more for their local impact than their effect on global warming

The lifecycle assessment (LCA) of the dairy sector produced by FAO (2010) includes many assumptions:

The average global emissions from milk production, processing and transport is estimated to be $2.4 \mathrm{~kg}$ of $\mathrm{CO}_{2}$ equivalent emissions per $\mathrm{kg}$ of FPCM (fat and protein corrected milk) at farm gate, but the variation regionally is very significant. Average regional emissions, per $\mathrm{kg}$ of FPCM at farm gate, range from 1.3 to $7.5 \mathrm{~kg}$ of $\mathrm{CO}_{2}$ equivalent [ $\left.\pm 26 \%\right]$. The highest emissions were found in developing regions with sub-Saharan Africa, South Asia, North Africa and the Near East with an average of 7.5, 4.6 and $3.7 \mathrm{~kg}$ of $\mathrm{CO}_{2}$ equivalent emissions per $\mathrm{kg}$ of FPCM, respectively. Industrialized regions such as Europe and North America had the lowest emissions per kg of FPCM.

The level of GHG emissions, per kg of FPCM, is higher in grazing systems than in mixed systems. Grassland systems contribute about $2.72 \mathrm{~kg}$ of $\mathrm{CO}_{2}$ equivalent emissions per $\mathrm{kg}$ of FPCM, compared to mixed systems which on average contribute $1.78 \mathrm{~kg}$. Along the entire dairy food chain, 'cradle-to-farm gate' emissions (i.e. from young calf to adult milking cow on farm) contribute the highest proportion of emissions (93\% on average). In industrialized countries, the relative contribution ranges between 78 and $83 \%$ (i.e. $20 \%$ of emissions occur after the milk has left the farm), while in developing regions the contribution ranged between 90 and $99 \%$ of total emissions. However, the assumptions and uncertainty in these LCA demands significant care in interpretation (FAO 2010). 
Cattle farming \& climate change influence wider environmental issues beyond GHG \& global warming. There are profound consequences for water availability, soil degradation, biodiversity and local ecology as well as conflict for energy supplies.

This paper seeks to explore the issue of climate change and cattle farming in four sections:

1. The impact of cattle farming on the environment

2. Measuring climate change impacts at farm level

3. Reducing the impact on climate change at farm level: Resource efficiency \& nutrition

4. Reducing the impact on climate change at farm level: Improved health \& productivity reduces the waste caused by disease and reproductive inefficiency

Although climate change impacts cattle farming through effects on water availability, heat stress (see figure 2) and flooding for example, this paper will mainly focus on how cattle farming impacts on climate change. Managing the complex and conflicting balance of factors required for sustainable food production in cattle farming offers an important role for the veterinary surgeon; this opportunity represents an underlying theme of this paper.

\section{The impact of cattle farming on the environment}

At a global level, livestock farming accounts for $40 \%$ of agricultural GDP, employs 1.3 billion people and supplies approximately one third of the protein consumed by the human population. Global production of meat is projected to more than double from 229 million tonnes in 1999/2001 to 465 million tonnes in 2050 and global milk production to double from 580 to 1043 million tonnes (FAO 2010). The environmental effects of each unit of livestock production must consequently halve in this time period just to prevent increased impact.

Cattle farming activities are socially and politically highly significant and impact on virtually all aspects of the environment. This impact may be direct, for example through emission of GHGs such as methane, or indirect, such as the expansion of soybean production for feed replacing forests in South America. However, the idea that ruminant agricultural systems are inherently inefficient methods of food production needs challenging; $70 \%$ of the world's agricultural area is grassland and much of this could not be converted to cereal production for mainly climatic reasons but also due to the risk of damage to ecosystems. In these areas ruminants can convert the grassland energy and protein (much of which is fibre bound or present as nonprotein nitrogen source) into human food. Furthermore, in countries with large foodprocessing industries, the disposal of food-residue is a significant issue and this residue can often be converted to milk or meat by ruminants.

However the livestock sector does still emerge as one of the top two or three most important influences on the environment, both at local and global levels (see Table 1).

Table 1. Areas of the environment that are potentially harmed by cattle farming (Green and others, 2011)

\begin{tabular}{|c|c|c|c|}
\hline $\begin{array}{l}\text { Area of } \\
\text { Environment }\end{array}$ & Sub categories & $\begin{array}{l}\text { Items that harm } \\
\text { environment }\end{array}$ & Further notes \\
\hline Atmosphere & Emissions & $\begin{array}{l}\text { Methane, nitrous } \\
\text { oxide, ammonia, } \\
\text { carbon dioxide }\end{array}$ & $\begin{array}{l}\text { Methane has } 23 \text { times and nitrous } \\
\text { oxide } 296 \text { times the global warming } \\
\text { potential of } \mathrm{CO}_{2} \text {. Cows produce around } \\
500 \text { litres of methane per day. Most } \\
\text { methane emissions are enteric, } \\
\text { whereas most nitrous oxide and } \\
\text { ammonia are from fertilizer/manure } \\
\text { application or manure storage. } \\
\text { Approximately } 40 \% \text { of GHG emissions } \\
\text { come from methane and around } 30 \% \\
\text { from fertilizer/manure management. } \\
\text { Methane production tends to be lower } \\
\text { per litre of milk produced in high input }\end{array}$ \\
\hline
\end{tabular}




\begin{tabular}{|c|c|c|c|}
\hline & & & $\begin{array}{l}\text { systems. Indirect emissions occur from } \\
\text { energy utilisation which tends to be } \\
\text { higher for high input systems. }\end{array}$ \\
\hline Soil & $\begin{array}{l}\text { Soil structure, } \\
\text { Pollution, } \\
\text { Ecological issues }\end{array}$ & $\begin{array}{l}\text { Loss of organic matter, } \\
\text { nutrient leakage, } \\
\text { reduced soil fertility, } \\
\text { erosion }\end{array}$ & $\begin{array}{l}\text { Generally worse with intensive land } \\
\text { management, reduced recycling of } \\
\text { animal waste and mechanical } \\
\text { overloading causing compaction. } \\
\text { Nitrogen losses often worse as } \\
\text { production level increases. }\end{array}$ \\
\hline Water & $\begin{array}{l}\text { Chemical: Surface } \\
\text { or ground water } \\
\text { pollution. } \\
\text { Water shortages }\end{array}$ & $\begin{array}{l}\text { Nitrogen, Potassium, } \\
\text { Phosphorus, } \\
\text { agrochemical } \\
\text { pollution. } \\
\text { High water usage by } \\
\text { dairy farming } \\
\text { (particularly more } \\
\text { intensive systems). }\end{array}$ & $\begin{array}{l}\text { Soil overload of manure or chemicals, } \\
\text { dependent upon local conditions } \\
\text { leading to leakage in surface or ground } \\
\text { water. May be aggravated by reduction } \\
\text { in soil permeability or storage capacity. } \\
\text { Suggestions that future global shortage } \\
\text { of water could be compounded by } \\
\text { dairy farming. }\end{array}$ \\
\hline $\begin{array}{l}\text { Energy } \\
\text { Consumption }\end{array}$ & $\begin{array}{l}\text { Gas emissions, use } \\
\text { of resources }\end{array}$ & $\begin{array}{l}\mathrm{CO}_{2} \text {, loss of non- } \\
\text { renewable resources }\end{array}$ & $\begin{array}{l}\text { Although a less important contributor } \\
\text { to gaseous emissions than } \mathrm{CH} 4 \text { (above), } \\
\text { energy use is greater in high input } \\
\text { systems, particularly for concentrate } \\
\text { feed production/processing (can be } \\
\text { mitigated by use of byproducts e.g. } \\
\text { Brewers Grains and Trafford Gold that } \\
\text { have not been pelleted) and the } \\
\text { worldwide transportation of cattle } \\
\text { feedstuffs. }\end{array}$ \\
\hline Local ecology & $\begin{array}{l}\text { Landscape } \\
\text { alteration and } \\
\text { biodiversity }\end{array}$ & $\begin{array}{l}\text { Loss of plant and } \\
\text { animal species, } \\
\text { reduced variation in } \\
\text { rural environments, } \\
\text { environmental } \\
\text { degradation. }\end{array}$ & $\begin{array}{l}\text { Both intensification and neglect can } \\
\text { threaten local landscapes and } \\
\text { biodiversity but the overall impact of } \\
\text { dairy farming on biodiversity is } \\
\text { uncertain. Cultivation of some } \\
\text { feedstuffs (e.g. soya in south America) } \\
\text { has led to deforestation and can have } \\
\text { deleterious effects on local ecosystems. }\end{array}$ \\
\hline
\end{tabular}

Figure $\mathbf{2}$ Managing heat stress in dairy cattle housing using fans; an emerging issue with climate change? 


\section{Atmosphere}

Livestock farming is responsible for around 3.5\% of total UK GHG emissions and has an obligation to reduce emissions in line with national and international agreements. A failure to reduce emissions would require larger cuts to be made in other areas, which is unlikely to be acceptable to governments and those industries involved.

Cattle farming results in the production of three of the four principal gases with global warming potential (GWP): carbon dioxide $\left(\mathrm{CO}_{2}\right)$, methane $\left(\mathrm{CH}_{4}\right)$ and nitrous oxide $\left(\mathrm{N}_{2} \mathrm{O}\right)$. Whilst overall, carbon dioxide is the most important GHG, methane and nitrous oxide make significant contributions. ' $\mathrm{CO}_{2}$ equivalent emission' is used to standardise the GWP of different gases; methane and nitrous oxide have 23 times and 296 times the GWP of $\mathrm{CO}_{2}$ respectively.

The most significant sources of GHG are the methane produced during enteric fermentation which is released when animals eructate and the methane and nitrous oxide released from mineral fertilizers, slurry (see figure 3) and manure (both when stored and spread). However, emissions are also generated from fuel and electricity produced from fossil fuels used for equipment and machinery on farm, and the production and transport of inputs and milk and milk products.

\section{Figure 3 GHG emissions occur with stored slurry and manure}

\section{Soil}

The banks of water courses, ponds, lakes and canals become poached and eroded over time if animals are allowed access. This reduces water quality by adding silt and faecal contamination and has the potential to increase phosphorus levels. Land degradation involves similar poaching of grazing land, feeding areas, gateways and tracks (see figure 4). Consequences include loss of organic matter, nutrient leakage, reduced fertility \& erosion. Widespread logging in South America and South East Asia to produce grazing land for beef cattle and to grow feed crops are examples of change in land use which compromises GHG control, and degrade water quality, land and biodiversity.

\section{Figure 4 Land degradation with poaching of gateways}

\section{Water}

Both ground and surface water may become contaminated either by a single event e.g. slurry discharging into a river, or from the cumulative result of agricultural activity over a prolonged time period. A range of different pollutants can contaminate water; most commonly nitrogen and phosphorus but also agrichemicals such as veterinary medicines, dairy chemicals, disinfectants, pesticides, herbicides and fuels.

\section{Nitrogen}

About $60 \%$ of the nitrates in English rivers come from agriculture. Chemical fertilizers and organic animal waste can cause nitrate pollution. Elevated nitrate levels can lead to eutrophication and algal bloom and in drinking water pose a risk to human health via methaemoglobinaemia caused by nitrate consumption. 
Within Europe the Nitrate Directive (1991) aims to protect water quality by promoting and legislating for good farming practices (Defra 2009). Member states are required to:

- Designate as Nitrate Vulnerable Zones (NVZs) all land draining to waters that are affected by nitrate pollution.

- Establish a voluntary code of good agricultural practice to be followed by all farmers.

- Establish a mandatory action programme of measures for the purposes of tackling nitrate loss from agriculture.

- Review the extent of their NVZs and the effectiveness of their action programmes at least every four years and to make amendments if necessary.

\section{Phosphorus}

Phosphorus is a component of chemical fertilizers and organic animal waste, however, it is largely insoluble and not prone to leaching. Phosphorus pollution is less stringently controlled than nitrogen pollution within Europe, although other parts of the world are subject to stringent control measures.

\section{Slurry, manure and other organic materials}

Slurry, manure, silage effluent and other organic materials such as milk and animal carcases can cause substantial damage if they escape into water courses. Microorganisms in the environment which break down the organic matter they contain deplete oxygen from water with serious, even catastrophic consequences for other aquatic life.

\section{Biodiversity}

Farming practices may have a huge impact on biodiversity as, almost by definition, most agricultural practices are trying to selectively exclude growth of other plants and pests. Hedgerows may be removed and heath, moor and marsh lands drained to create uniform pastures for grazing. Developments in plant science, herbicides, pesticides and fertilizers create near perfect monocultures of forage crops and cereals for feed. In many parts of the world ancient and complex ecosystems (e.g. the rain forests of South America) are being destroyed to make way for intensive agriculture. The same is true in areas of the USA and Europe where the 'maize silage and soya' system of dairying has started to predominate in the last 20 years. Maize is a nutrient hungry and pesticide dependent crop that is protein deficient for dairy cows and hence requires extra protein (often soya) to make up this deficiency.

\section{Promoting and Enforcing Environmental Protection}

Schemes to promote and enforce environmental protection are vital if national and international goals and targets are to be met. Approximately $70 \%$ of England's farmland is currently covered by environmental management or stewardship schemes. Within the UK, the Environment Agency, an executive non-departmental public body, has responsibility for water and pollution control. Until recently, two UK departments (Energy \& Climate Change (DECC) and Environment Food and Rural Affairs (DEFRA)) governed policy in the area, which can create conflict and limit optimal management. 


\section{Measuring climate change impacts at farm level}

Quantitatively evaluating all components of a dairy or beef business that have an environmental impact is not trivial. Such a scoring system would need to include beneficial and detrimental effects of all aspects of the farm including the pathways of products brought onto and taken off farm. The weighting of different components is not clear cut and neither are 'environmental costs' of changing to different systems. For example, if improved biodiversity is at the expense of increased greenhouse gas (GHG) emissions, which is more valuable in an environmental context?

\section{Carbon foot-printing}

One method currently employed is that of whole farm 'carbon foot-printing' (see figure 5). This involves examining data from all aspects of the farming enterprise that cause production of methane, nitrous oxide and carbon dioxide and calculating the total $\mathrm{CO}_{2}$ equivalents per litre of $4 \%$ butterfat corrected milk or kilograms $(\mathrm{kg})$ of beef produced. There are several ways to break this down but the main categories and sub categories are:

- Livestock - purchased feed, bedding, enteric fermentation, manure management, purchase/contract rearing

- Cropping - fertilizer manufacture and spreading, manure spreading

- Fuel and Energy - total usage

Quantitative models take a relative weighting of these different categories into account. For instance, artificial fertilizer production carries a high environmental cost due to the quantity used on farm and also the quantity of $\mathrm{N}_{2} \mathrm{O}$ produced in its manufacture.

Figure 5 Heat exchange unit in a farm dairy; what factors are included when carbon footprinting dairy or beef production?

\section{Life Cycle Assessment (LCA)}

The technical report 'Greenhouse Gas Emissions from the Dairy Sector: A Life Cycle Assessment' (FAO 2010) is part of a wider Food and Agriculture Organisation (FAO) study aiming to identify low carbon pathways for the entire livestock sector. It focuses on the dairy food chain, encompassing the life cycle of dairy products from the production and transport of inputs (fertilizer, pesticide, and feed), land use change (deforestation related to soybean production), milk transport (farm to dairy and from processor to retailer) and processing, the production of packages, and the distribution of products to retailers. Emissions are reported in 'per $\mathrm{kg}$ of fat and protein corrected milk (FPCM)' units and are summarised in table 2 below:-

Table 2. Overall dairy sector contribution to global GHG emissions

In 2007 the dairy sector emitted 1969 million tonnes of $\mathrm{CO}_{2}$ equivalents (+/-26\%) of which 1328 million tonnes were attributed to milk, 151 million tonnes to meat from culled animals and 490 million tonnes to meat from fattened calves 
The global dairy sector contributes $4 \%$ to total global anthropogenic GHG emissions (+/- 26\%)

The overall contribution of global milk production processing and transportation to total anthropogenic GHG emissions is $2.7 \%$ (+/- 26\%)

Average global emissions from milk production processing and transport is estimated at $2.4 \mathrm{CO}_{2}$ equivalents per $\mathrm{kg}$ of FPCM (+/- 26\%)

\section{Marginal Abatement Cost Curves (MACC)}

Marginal abatement cost can be used to measure the cost of reducing a unit of pollution. There is potential for worthwhile "win-win" outcomes for both farm profits and sustainable food production by cost-effectively reducing GHG emissions in the cattle sector through implementing measures to control endemic diseases and improve productivity. MACCs have been developed across a number of sectors to identify the most economically efficient reductions in GHG. Specific MACC for endemic cattle disease control have been proposed, as in fig 6 below (ADAS 2013).

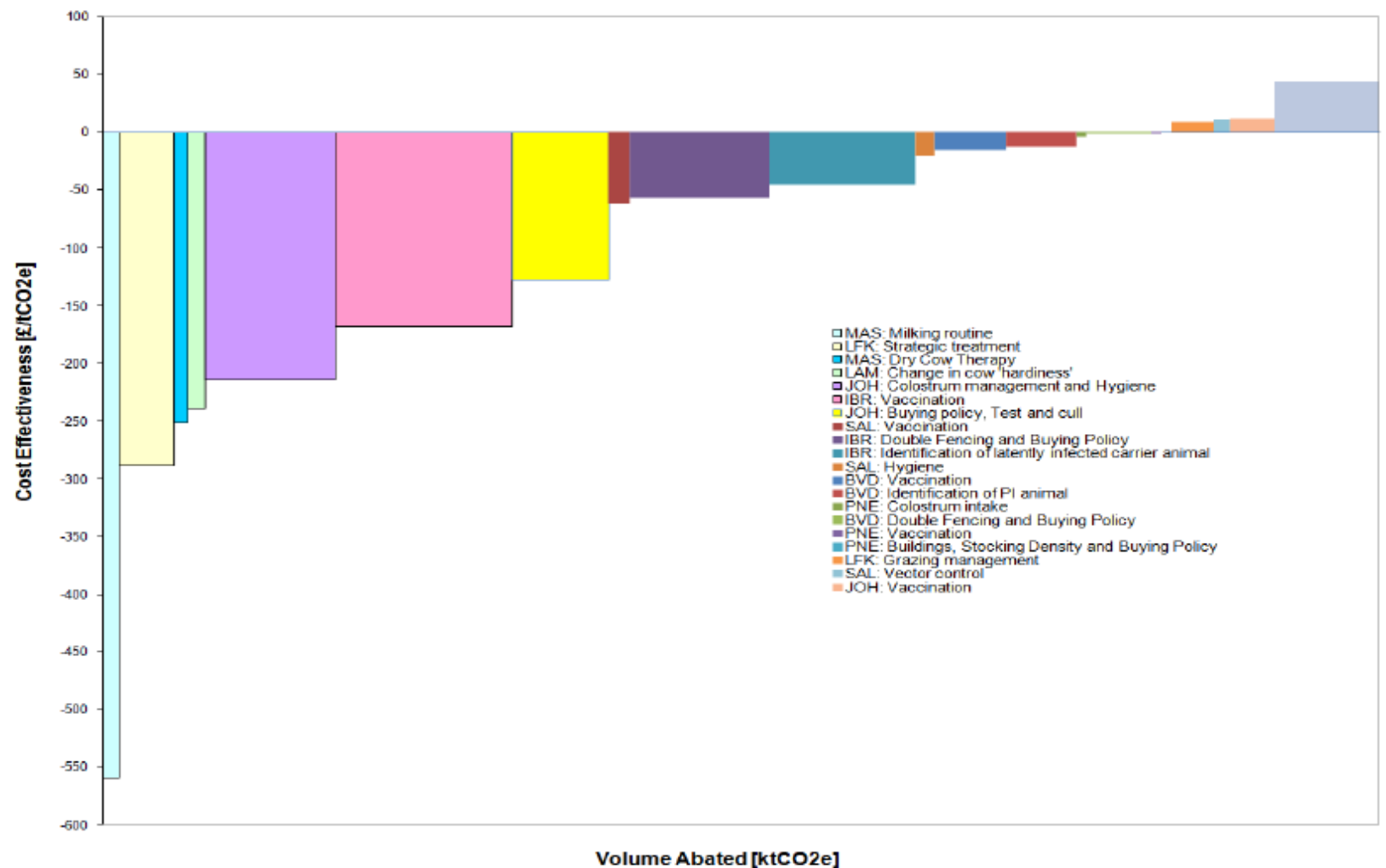

Fig. 6 Marginal abatement cost curve (MACC) for control of cattle endemic disease in the UK (ADAS 2013) 


\section{Reducing the impact on climate change at farm level: Resource efficiency \& nutrition}

There are essentially three main areas of opportunity to mitigate the impact of cattle farming on climate change, as summarised in table 3 below:

- Resource efficiency \& environmental management measures

- Nutrition \& modification of enteric fermentation

- Improved health \& productivity by reducing the waste caused by disease and reproductive inefficiency

Table 3. Outline of methods to reduce the environmental impact of dairy farming (Green and others, 2011)

\begin{tabular}{|c|c|}
\hline $\begin{array}{l}\text { Area of } \\
\text { Improvement }\end{array}$ & Suggested Methods for improvement \\
\hline Soil & $\begin{array}{l}\text { Aeration if compacted. Conduct soil analysis to precisely evaluate what } \\
\text { additives are required. Technologies for measuring and differential } \\
\text { application of additives in different locations are at the heart of the } \\
\text { 'precision agriculture' revolution currently taking place. Improve swards } \\
\text { with minimal soil disturbance (reduces } \mathrm{N}_{2} \mathrm{O} \text { losses) e.g. oversewing, direct } \\
\text { drilling. }\end{array}$ \\
\hline Water & $\begin{array}{l}\text { Reduce dietary protein as far as possible - the use of essential oils and more } \\
\text { precise rationing to individual amino acid requirements decreases overall } \\
\text { crude protein requirement down from } 17-18 \% \text { (by dry matter) to } 15-16 \% \\
\text { even in high yielding animals. Adhere to NVZ regulations if applicable. } \\
\text { Excess dietary phosphorus will be excreted in urine and faeces and is a } \\
\text { potential cause of eutrophication. Therefore check dietary content so that } \\
\text { mineral specifications are not excessive for phosphorus. }\end{array}$ \\
\hline Manure/slurry & $\begin{array}{l}\text { Storing solid rather than liquid manure can reduce methane but increase } \\
\mathrm{N}_{2} \mathrm{O} \text {. Compacting manure and covering slurry stores or manure heaps } \\
\text { reduces Ammonia / } \mathrm{N}_{2} \mathrm{O} \text {. Slurry application; lower } \mathrm{N}_{2} \mathrm{O} \text { emissions if spread } \\
\text { in Spring compared to Autumn/Winter. Understand nutrient content of } \\
\text { slurry/manure and match to crop requirements, allowing for ground type } \\
\text { and } \mathrm{NVZ} \text { rules. Direct injection reduces ammonia and } \mathrm{N}_{2} \mathrm{O} \text { compared to } \\
\text { surface spreading. Consider anaerobic digestion to capture and utilise } \\
\text { methane which can be used as an energy source on farm. }\end{array}$ \\
\hline Nitrogen & $\begin{array}{l}\text { Effective } \mathrm{N} \text { utilisation - understand soil and crop requirements and match } \\
\text { with fertilizer rates, maximise use of organic manures - reduces } \mathrm{N}_{2} 0 \text {, } \\
\text { ammonia and nitrate losses. } \\
\text { Feeding so as not to provide excess } \mathrm{N} \text { in diet. }\end{array}$ \\
\hline $\begin{array}{l}\text { Health } \\
\text { fertility. }\end{array}$ & $\begin{array}{l}\text { Optimising efficiency of production - fewer cows and less waste milk } \\
\text { reduces the environmental impact per litre sold - A major veterinary role } \\
\text { (see below). }\end{array}$ \\
\hline Diet & $\begin{array}{l}\text { Effective use of feed improves performance and reduces inputs and waste } \\
\text { per litre of milk produced: High dry matter intakes, high quality forage, high } \\
\text { sugar forage, use of clover, addition of specific oils or other feed additives } \\
\text { to reduce methane emissions are current areas of research. }\end{array}$ \\
\hline
\end{tabular}




\begin{tabular}{|ll|}
\hline Housing & $\begin{array}{l}\text { More frequent slurry removal reduces ammonia emissions. Bolder and } \\
\text { longer term strategies could include scavenging greenhouse gases from } \\
\text { negatively ventilated, sealed buildings. Collected gases could be re-used on } \\
\text { farm e.g. methane. }\end{array}$ \\
\hline Genetics & $\begin{array}{l}\text { It may be possible to select for 'low emission' animals by making use of the } \\
\text { relatively large between animal variations that exists in emission } \\
\text { characteristics. Selecting for more efficient and resilient animals may } \\
\text { mitigate GHG production. }\end{array}$ \\
\hline $\begin{array}{l}\text { Energy } \\
\text { consumption / } \\
\text { CO emissions }\end{array}$ & $\begin{array}{l}\text { Review energy use and consider energy saving changes to lighting, } \\
\text { machinery, dairy equipment (e.g. plate coolers, heat recovery units), reduce } \\
\text { delivery numbers (increase storage capacity), use of local feeds or by- } \\
\text { products. } \\
\text { Consider 'carbon storage'; e.g. conversion of cultivated land to permanent } \\
\text { pasture or woodland. Consider production of energy from renewable or } \\
\text { home produced sources. }\end{array}$ \\
\hline
\end{tabular}

\section{Resource efficiency and environmental management measures}

Many environmental improvements can be made that have associated financial benefits.

Methods to reduce potentially deleterious environmental impacts may divide into:

- Improved efficiency; e.g. variable demand precision fans or milk pumps

- reduced emissions; e.g. using covers on slurry stores

Some common areas that lead to significant financial savings are outlined in Table 4.

Table 4. Resource efficiency and environmental management measures

Resource efficiency and environmental management measures

Segregating roof water for washing down parlour standings

Using plate coolers to cool milk

Testing nutrient value of manures and producing a nutrient plan matched to slurry analysis

Direct slurry injection to reduce nitrogen losses and anaerobic spoilage

Using fuel efficient tractors

Using grass and forage types or strains with better nitrogen usage efficiency

Use of silage inoculants or preservatives to improve fermentation and aerobic stability to reduce clamp wastage

Changes to slurry management practices to reduce nitrous oxide emissions e.g. avoid application when grass growth is slow

The use of anaerobic digesters to reduce the emissions from manure and to produce green electricity (see figure 6)

Recycling bedding, in particular sand. Recycled manure solids are currently the subject of much research and debate in the UK

Efficient energy use in the supply chain both pre and post farm

Increasing the energy efficiency of dairy equipment and farm machinery through effective insulation \& heat recovery and GPS precision cropping, or increasing the use of energy from renewal sources

Using more home grown protein feeds to reduce emissions associated with transport 
Periodically, grants have become available to help finance investments that contribute to improvements to areas of environmental concern. Solar panels, wind turbines and anaerobic digesters (see figures $\underline{7-96}-8$ ) have rapidly become established on cattle farms, off-setting the climate change impact through the generation of 'green' renewable energy.

Figure 7 Solar panels installed on the roof of a cattle building

Figure 8 Electricity generation from a wind turbine on a cattle farm as part of an integrated farm business strategy

Figure 9 Anaerobic digestion on a dairy cattle farm

\section{Nutrition and modification of enteric fermentation}

Enteric fermentation generally provides more significant GHG impact than manure management. Mitigation methods include changing management towards high milk output systems away from more extensive grazing systems, although debate still continues over the role of grassland as 'carbon sinks' and silvopastoral systems (Broom and others 2013). Other solutions are based more around dietary changes:

\section{i. Dietary formulation to optimise carbohydrate utilisation}

Feeding more starch and less fibre (see figures 109 \& 11ㅇ) means relatively more propionate and relatively less acetate and butyrate are produced in the rumen, leading to reduced $\mathrm{CH}_{4}$ production. A herd producing 8000 litres of milk per annum, that has a relatively high starch content in the diet will have approximately $5 \%$ lower $\mathrm{CH}_{4}$ production per litre (assuming an equivalent feed rate) than a herd producing the same milk with a lower dietary starch content and higher digestible fibre. However, high starch based diets have the potential to cause acidosis and subsequent deleterious effects on cow health and welfare. This is an example of a potential conflict between environmental and cow considerations; which is the more important?

\section{Figure 10 Measuring individual feed intakes and 'precision farming'}

\section{ii. Improving forage nutrition value}

Producing high quality forage does not appear to significantly reduce the emission of methane (-3\%), however scenarios modelling an increase in forage production but of lower quality have resulted in raised methane emissions. 


\section{iii. Strategic use of dietary oil supplements}

Lipid inclusion in the diet causes a marked decrease in $\mathrm{CH}_{4}$ production; in the order of $14 \%$, with the effect being at least partly governed by the fat source used. This effect is partially mediated by the depression of protozoal numbers in the rumen, but may also impact on methanogenic bacteria. Rumen protozoa have been shown to harbour approximately $25 \%$ of the methanogens in the rumen and lipids appear to represent one of the few practical methods of controlling protozoa in vivo. However, fat inclusion in the diet (particularly at levels above $50 \mathrm{~g} / \mathrm{Kg} \mathrm{DM}$ ) can adversely affect rumen health by significantly inhibiting fibre breakdown.

Another example of a conflict of interest is the use of palm oils in dairy cow diets. Milk price in some purchasing contracts depends on the percentage of butterfat in milk and considering farm profitability alone, it can be cost effective to boost butterfat by using palm oils (C16 fatty acids). The production of palm oil is generally considered to be severely detrimental to the environment.

\section{iv. Modification of the rumen microflora population}

\section{a. Use of ionophore supplements}

There are potential methane-reducing effects from feeding ionophores such as monensin, now licensed in the EU for the control of ketosis as an individually targeted bolus treatment. It is commonly used worldwide as a feed supplement on a group basis but growth promotors are generally banned in the EU.

Given the EU wide ban on the use of sub-therapeutic levels of antibiotics and ionophores as growth promoters, there has been an explosion of interest in other compounds that might modify microbial activity in the gut. With regards to $\mathrm{CH}_{4}$ production, attention has focussed on plant secondary metabolites, probiotics and propionate precursors. Whilst major EU funded projects on plant materials to decrease $\mathrm{CH}_{4}$ production are under way, possibly the most promising approach in the short term is the use of propionate precursors such as malate and fumarate. Some unsaturated oils such as linseed and some essential oils such as extracts from horse radish and garlic may reduce $\mathrm{CH}_{4}$ production. More research in this area is needed.

\section{b. Immunisation}

Immunising ruminants against their own methanogens can successfully reduce the numbers of Streptococci and Lactobacilli in the rumen with associated decreases in $\mathrm{CH}_{4}$ output. This approach is of particular interest in beef and sheep production, where extensive grazing remains the cornerstone of nutrition.

A number of nutrition based $\mathrm{CH}_{4}$ mitigation measures have been suggested and identified, but there is a need to know whether these would be effective over broad spatial scales and under future scenarios. Additionally, it is necessary to ascertain whether widespread implementation of these mitigations would have other consequences, e.g. for levels of production and emissions of other pollutants; the nitrogen based GHG do not always follow the same trends in mitigation as for $\mathrm{CH}_{4}$. 


\section{Reducing the impact on climate change at farm level: Improved health \& productivity reduces the waste caused by disease and reproductive inefficiency}

UK dairy businesses in the top $25 \%$ of performance (measured by cost of production) produce milk with a carbon foot print of over $300 \mathrm{~g} \mathrm{CO}_{2}$ less per litre than farms in the bottom $25 \%$. Improved health and reproductive performance drives this difference; for each day that a calving interval is extended there is an estimated increase of $18 \mathrm{~kg} \mathrm{CO}$ produced per cow per day. An increase in milk yield per cow (by $30 \%$ in the modelled scenario), coupled with a reduction in dairy cow numbers to maintain current levels of production produced the greatest impact on reductions to methane emissions in the UK (Chadwick and others 2007). A reduction in the milk yield per dairy cow by $30 \%$, coupled with an increase in the number of dairy cows required to maintain national milk production, resulted in an increase in $\mathrm{CH}_{4}$ emissions by almost $15 \%$.

Beef and sheep production account for around $65 \%$ of the total UK agricultural $\mathrm{CH}_{4}$ emission, but it has generally been assumed that there is less scope for mitigation in these more extensive systems. However, improved health and reproductive performance will represent financial and environmental 'win-wins' for dairy and beef industries alike and so the mitigation avenues discussed below may apply equally to both sectors.

\section{i. Improved health}

A reduction in GHG and use of non-renewable resources and chemicals, per litre of saleable milk or kg of carcase beef, is an inevitable consequence of improved health and fertility because fewer cows at a given level of production, are required to produce the same quantity of milk or beef. For example, a reduction in clinical mastitis in dairy production mitigates environmental impact as fewer litres of milk are discarded and udder tissue damage is prevented and prevention of respiratory disease in beef production mitigates impact as daily liveweight gain is not reduced (Statham and others 2012).

\section{ii. Increased sustainable yield}

Increasing the rate of productivity per head by feeding a more concentrated diet or by improving the nutritional value of the forage offered, would decrease $\mathrm{CH}_{4}$ production per unit of production, providing any increases achieved do not negatively impact on the health and fertility of the herd or the nutritional value of the milk produced. It is argued that maize silage and soya dominated feeding systems decrease the ratio of omega 3: omega 6 fatty acids in the milk and this may have negative effects on human health.

Dairy cow milk yields have increased more rapidly than dry matter intake during the past 25 years, due to genetic improvements and increased use of high energy diets resulting in improved efficiencies of rumen fermentation and feed digestibility. High milk producing cows, with higher feed intakes and enteric methane outputs, are associated with lower methane outputs per kilogram milk. There is a need to adopt management practices and technologies that improve productive efficiency while resource use and environmental impact are minimised. 


\section{iii. Reduced forced culling}

The performance-lifetime of a dairy cow is around 3.1-3.4 lactations or 36-40 months, and this must be set against a period of 24-30 months from birth to first calving. Calving heifers earlier and increasing the number of lactations for which the average cow remains economically productive would significantly reduce $\mathrm{CH}_{4}$ emissions from the UK dairy industry. Similarly extending the productive life of beef cows mitigates environmental impacts of beef production.

\section{iv. National cattle health schemes}

Improving productivity nationally through control of key endemic diseases is an approach being embraced across dairy and beef sectors. Although national schemes to improve mastitis and lameness control are targeted at the dairy sector, initiatives to control bovine viral diarrhoea virus (BVDV) are seeing success in Scotland, Ireland and widely across Europe led by the Scandinavian countries. Bovine tuberculosis (bTB) remains a significant cause of wastage in the UK; whilst a range of control strategies are being implemented, there appears little cause for optimism regarding eradication in the short to medium term.

\section{vi. Improved reproductive performance}

Suboestrus and poor oestrus detection leads to reduced submission rates to service and inefficient dairy or beef herd performance: delays in calving to conception, prolonged lactations, lower reproductive efficiency \& 100-day in-calf rates and higher 200-day not incalf rates. Garnsworthy (2004) used a modelling approach to predict the effects of fertility on emissions by constructing a model that linked changes in fertility to herd structure, number of replacements, milk yield, nutrient requirements and gas emissions. Fertility has a major effect on the number of heifer replacements required to maintain herd size for a given number of cows. Herd replacements produce up to $27 \%$ methane and $15 \%$ ammonia of the herd's total at typical commercial fertility levels. Improving submission rate from $50 \%$ to $70 \%$ could reduce emissions of methane by up to $24 \%$ and ammonia by about $14 \%$ (Garnsworthy 2004). Improved submission rate could represent one approach to achieving improved environmental sustainability for a fixed level of dairy or beef production.

\section{vii. Role of Genetics \& reproductive technologies}

A range of different breeding strategies, such as traditional genetic selection methods to improve production efficiency or biotechnology tools such as semen sexing could be used to mitigate the global warming impact of farm livestock. In the future, it may be possible to selectively breed animals with low methane production (there are variations between the emissions of individuals). Embryo collection and transfer, ovum pick-up and in vitro production all offer techniques for accelerated selection of sustainable production traits.

Bell and others (2010) investigated (1) the effect of long-term breeding for kilograms of milk fat plus protein production and (2) the influence of parity, genetic line and diet on predicted methane emissions of Holstein Friesian dairy cows, using 17 years of experimental data from the Langhill herd in Scotland. This herd comprises genetic lines selected for increased kilograms of milk fat plus protein (Select) or selected to remain close to the UK average (Control). 'Select' cows had a higher weekly DMI and milk yield but a lower predicted methane output per kg milk by approximately $12 \%$ when compared to 'Control' animals. In 
terms of diet, low-forage cows had a higher daily DMI and milk yield but a lower predicted methane output per kg milk than the high-forage cows.

\section{viii. Genomics \& Big Data: Breeding for Resilience \& Production Efficiency}

Many of the mitigation opportunities discussed above include a genetic component. Genomic selection has developed rapidly to the point where it is now being deployed commercially. Although mostly in the Holstein dairy breed, initiatives are underway to develop genomic selection in other breeds, both milk and meat-producing. The challenge is now to target the most appropriate traits.

If production efficiency is measured over the lifespan of the animal it is evident that the ability to carry on producing becomes a positive attribute. Being able to select animals with 'resilience' for a particular farm system could increase efficiency and reduce environmental impact. Evaluating such resilience relies on the ability to phenotype the key components on a sufficiently large scale to create the necessary reference populations for genomic evaluation. In this way, evidence-based breeding and culling decisions could be made using 'big data'; the large volumes of field data that potentially facilitate more efficient 'precision farming'.

\section{ix. Cattle Farming and climate change: A Role for the Veterinary Surgeon}

Improving health and fertility leads to a reduction in GHG emissions because fewer cows at a given level of production will be required to produce the same quantity of milk or beef. Therefore, an active herd health management programme should fundamentally reduce the climate change impact of food production. This offers clear practical opportunities for the cattle veterinary surgeon working in practice, as summarised in table 5 below:

Table 5. Practical climate change mitigation opportunities for the cattle veterinary surgeon working in practice

\begin{tabular}{|c|l|}
\hline $\begin{array}{l}\text { MITIGATION OPPORTUNITY } \\
\text { impacts }\end{array}$ & METHOD OF VETERINARY INPUT \\
\hline Resource efficiency & $\begin{array}{l}\text {-record \& report data of health, } \\
\text { production and reproductive events to } \\
\text { facilitate evidence based mitigation } \\
\text { strategies and costings }\end{array}$ \\
\hline -input to sustainable building design, track \\
construction in catchment sensitive water \\
areas and support applications for \\
renewable energy systems \\
\hline -engage with nutritionists and the farm \\
team to balance the conflicts between \\
health \& welfare, production and GHG \\
production \\
\hline Health & -lead the farm team in measuring, \\
& managing and monitoring herd health \\
& through proactive advisory services \\
\hline Reproduction & -lead the farm team in sustainable \\
& reproductive management, including \\
& regular fertility visits and integrated herd \\
\hline
\end{tabular}




\begin{tabular}{|l|l|}
\hline & $\begin{array}{l}\text { health strategies including addressing the } \\
\text { root causes of infertility such as infectious } \\
\text { disease and nutrition, alongside bull and } \\
\text { Al performance including semen quality } \\
\text { and synchronisation techniques where } \\
\text { appropriate }\end{array}$ \\
\hline Genetics & $\begin{array}{l}\text {-engage with an opportunity for veterinary } \\
\text { advisory input to shape the future of } \\
\text { cattle farming through genomics }\end{array}$ \\
\hline Welfare & $\begin{array}{l}\text {-prioritise high welfare to promote the } \\
\text { added value of high welfare dairy } \\
\text { production to the consumer }\end{array}$ \\
\hline
\end{tabular}

The veterinary surgeon in practice has a key role at the hub of the farm team to deliver an appropriate balance (see figure 12):

\section{Food production}

-sustainable

-safe/secure

-profitable

Environmental management

-soil/water/air

-energy

-diversity

\section{Animal health \& welfare}

-A life worth living

-Five freedoms

-Vet as a custodian

-Consumer beliefs

\section{Antimicrobial}

Resistance \&

'One Health'

-responsible use of medicines

Figure 12. Veterinary Herd Health Management and the Environment 
Undoubtedly future challenges including globalisation of food markets, national and global population growth, consumer demands for better welfare and the 'one health' agenda regarding antimicrobial resistance related challenges between human medicine and veterinary medicine will create complex conflicts. The veterinary surgeon has a role to play in achieving an appropriate balance in cattle farming. What may happen in the future in terms of cattle and the environment is far from clear and is certain to be politically driven. Some areas where change should occur are described in table 6 below:

Table 6. Future changes in cattle farming and the environment

\section{Future changes in Cattle farming \& the Environment}

Development of a better holistic understanding of the true environmental impact of different dairy and beef farming methods and systems.

Relevant research on how to reduce the environmental impact of livestock farming.

Discussion and progress in areas where there is conflict between cow welfare and the environment

Alteration of some farming methods to be acceptable to modern society in terms of environment and welfare.

Accurate measurement of important diseases on a national basis.

Inclusion and progression of the veterinary profession such that it delivers an evidence-

based, co-ordinated approach to cow health and reproduction on a national basis.

\section{Conclusions}

The environmental impacts of cattle farming are now well recognised. Whilst it is important that agriculture deflects unnecessary scaremongering, it is also important that measures are taken to develop and introduce improvements that will lead to sustained reductions in climate change impacts in the long term. The veterinary profession has the opportunity to be central to this process. Cattle farming is associated with climate change and this paper outlines how these impacts may be measured. However, this paper also describes the critical roles that veterinary surgeons may play in this area and the potential importance for redefining cattle veterinary practice by considering the need to balance food production with health \& welfare, AMR, 'one health' \& the environment.

\section{Further Reading}

ADAS (2013). Study to Model the Impact of Controlling Endemic Cattle Diseases and Conditions on National Cattle Productivity, Agricultural Performance and Greenhouse Gas Emissions. Defra Report AC0120

BELL, M.J., WALL, E., RUSSELL, G., MORGAN, C. andAND SIMM, G. (2010) Effect of breeding for milk yield, diet and management on enteric methane emissions from dairy cows. Animal Production Science 50, 817-826

BROOM, D. M. GALINDO, F. A. and and MURGEITIO , E .(2013) 
Sustainable, efficient livestock production with high biodiversity and good welfare for animals Proc. R. Soc. B 2013 280, 20132025.

CHADWICK, D.R., DEL PRADO, A., MILLS, J.A.N., CROMPTON, L.A., DRAGOSITS, U., SCHOLEFIELD, D., NEWBOLD, J.C. (2007) The implications of farm-scale methane mitigation measures for long-term national methane emissions. Final report to DEFRA on project CCO270.

DEPARTMENT OF THE ENVIRONMENT, FOOD AND RURAL AFFAIRS (2009). Protecting our Water, Soil and Air. A Code of Good Agricultural Practice for Farmers, Growers and Land Managers. DEFRA

FOOD AND AGRICULTURE ORGANIZATION OF THE UNITED NATIONS (2006). 'Livestock's long shadow'. FAO.

FOOD AND AGRICULTURE ORGANIZATION OF THE UNITED NATIONS (2010). 'Greenhouse gas emissions from the dairy sector. A life cycle assessment'. FAO.

GARNSWORTHY, P.C. (2004).The environmental impact of fertility in dairy cows: a modelling approach to predict methane and ammonia emissions. Animal feed science and technology $112 ; 211-223$

GREEN, M.J., HUSBAND, J.A., HUXLEY, J.N., STATHAM, J.M.E, (2011) Role of the Veterinary Surgeon in managing the impact of Dairy Farming on the Environment:. In Practice 33, 366373.

IPCC, 2014: Summary for policymakers. In: Climate Change 2014: Impacts, Adaptation, and Vulnerability. https://ipcc-wg2.gov/AR5/images/uploads/WG2AR5_SPM_FINAL.pdf

KYOTO PROTOCOL CONVENTION 1998 Kyoto Protocol to the United Nations Framework Convention on Climate Change (1998), art 3.1.

STATHAM, J.M.E., GREEN,M.J., HUXLEY, J.N., STATHAM, S. (2012) Dairy Farming, Food Security and Environmental Issues in Dairy Herd Health ed. Green, M. J. CABI (Ch.9)

STATHAM, J.M.E., GREEN, M.J., HUXLEY, J.N., STATHAM, S. (2015) Sustainable food production and dairy herd health. A key role for the veterinary surgeon' in Food Security. Challenges, role of biotechnologies and implications for developing countries; p.13-38 


\section{for In Practice 25 August 2016}

1) The UK Climate Change Act (2008) outlines one of the most ambitious national climate change programmes, targeting reduced GHG emissions, compared to 1990 levels, of:
a) $4 \%$ by 2020 and $8 \%$ by 2050
b) $14 \%$ by 2020 and $28 \%$ by 2050
c) $58 \%$ by 2020 and $64 \%$ by 2050
d) $25 \%$ by 2020 and $75 \%$ by 2050
e) $34 \%$ by 2020 and $80 \%$ by 2050

2) Of the five major sectors that make up total Green House Gas (GHG) emissions:

- Energy

- Industry

- Waste

- Land use, land use change \& forestry (LULUCF)

- Agriculture

what contribution were livestock activities postulated to contribute by United Nations Food \& Agriculture Organisation (FAO) in 2006:

a) an estimated $58 \%$ to these total GHG emissions

b) an estimated $18 \%$ to these total GHG emissions

c) an estimated $34 \%$ to these total GHG emissions

d) an estimated $72 \%$ to these total GHG emissions

e) an estimated $8 \%$ to these total GHG emissions

3) Which ONE of the following options does NOT represent an area of opportunity to mitigate the impact of cattle farming on climate change based on nutrition and modification of enteric fermentation:

a) Feeding a high forage diet of low digestibility

b) Strategic use of dietary oil supplements

c) Feeding more starch and less fibre

d) Use of ionophore supplements

e) Immunising ruminants against their own methanogens

4) Which of the following do NOT represent areas of opportunity to mitigate the impact of cattle farming on climate change through health \& reproduction management:

a) Increased submission rate to service

b) Control of Bovine viral diarrhoea virus (BVDv)

c) Control of liver fluke

d) Calving replacements into the adult cattle herd at THREE years old rather than TWO years old

e) Control of mastitis

Answers: e), b), a), d) 